\title{
Child Marriage: A Discussion Paper
}

\author{
Tahera Ahmed \\ Former Acting Chief, SRHR, UNFPA\& \\ Editor, Bangladesh Journal of Bioethics \\ Email: tahera50@yahoo.com
}

\begin{abstract}
Child marriage is still a massive problem in many developing countries. The issue is more concentrated in countries of Sub Saharan Africa and South Asia. This paper, through literature review attempts to assess the situation, the consequences, various programmes and recommendations on the reduction of child marriage. In this article it is reinforced that, consequences of child marriage put the girls at risk of early pregnancies with life-threatening conditions. This paper suggests that each country should set up its own midterm and long-term goals to bring about significant reduction in child marriages.
\end{abstract}

Key Words: child marriage, consequences, traditions, education, security, poverty

BACKGROUND: Child Marriage defined as marriage before the age of 18 - applies to both boys and girls, but it ismore common among young girls ${ }^{1}$. The issue of Child marriage is such a reality in many countries that it was not questioned for years together and was accepted as the norm. With the advent of development the adverse effects of child marriage was recognized and comparisons were made with advanced countries were age of marriage below 18 was a thing of the past and men and women have equal access to education, employment and their own personal growth and advancement. The Convention of the Rights of the Child (CRC) also set the minimum age of reaching adulthood. According to Article 1 of the CRC "any human being below the age of 18 is a child," the CRC has been ratified by 194 countries $^{2}$.

Those countries still having early marriage i.e. below 18 years also exhibit poor indicators relating to the MDGs. They usually have high maternal mortality and morbidity rates, low education levels for girls, especially secondary education, and overall high poverty levels.

PRESENT SITUATION:Though 158 countries have set the legal age for marriage at 18 years, laws are not enforced. The practice of marrying young children is upheld by tradition and social norms. Many countries of Asia and Sub Saharan Africa still have a high percentage of Child marriages (Table 1) thereby making their struggle for development particularly difficult.One third of girls in the developing world are married before the age of 18 and 1 in 9 are married before the age of fifteen (15). In 2012, 70 million women 20-24 around the world had been married before the age of $18^{3}$. South Asia has the largest number of child brides with almost half of girls married by 18 while in sub-Saharan Africa it is more than one third.

CONSEQUENCES OF CHILD MARRIAGE:From the above table it is evident that even in this era, child marriages are quite prevalent in many countries. Often new brides are expected to demonstrate their fertility after marriage specially by producing a male heir. According to UN 16 million adolescent girls give birth every year and the major cause of death for girls aged 15-19 years in these countries is due to complications during pregnancy and childbirth ${ }^{3}$.According to UNICEF around 50,000 girls die during pregnancy, mostly in low and middle-income countries.

The prevalence of stillbirths and new born deaths are 50 per cent higher in mothers who are below 20 years of age ${ }^{3}$."These children, because that's what they are, are discouraged from using contraceptives or might have to ask their husbands' permission, or they have no knowledge of or access to what they need," says Carole Presern, PhD, Executive Director of The Partnership for Maternal, Newborn \& Child Health ${ }^{4}$.

"Even though some parents believe early marriage will protect their daughters from sexual violence, the reverse is often true," according to a Joint press release by UNFPA, UNICEF, WHO, UN Women, the United Nations Foundation, World Vision, Girls Not Brides, Every Woman Every Child, World YWCA and The Partnership for Maternal, New born and Child Health, dated 07 March $2013^{3}$. The Press release states that "young girls who marry before the age of 18 have a greater risk of becoming victims of violence. This is especially true when the age gap between the child bride and spouse is large" A study conducted by ICRW ${ }^{5}$ in two states in India (Bihar and Jharkand) found that girls who were married before 18 were twice as likely to report domestic violence. These child brides also showed signs of severe depression. Child marriage often leads to deterioration of the health of girls. Due to complications during pregnancy and childbirth many girls in developing countries die or 
The table 1 depicts the situation globally:

\begin{tabular}{|c|c|c|}
\hline Rank & Country Name & $\%$ Girls Married before 18 \\
\hline 1 & Niger & 75 \\
\hline 2 & Chad & 68 \\
\hline 3 & Central African Republic & 68 \\
\hline 4 & Bangladesh & 66 \\
\hline 5 & Guinea & 63 \\
\hline 6 & Mozambique & 56 \\
\hline 7 & Mali & 55 \\
\hline 8 & Burkina Faso & 52 \\
\hline 9 & South Sudan & 52 \\
\hline 10 & Malawi & 50 \\
\hline 11 & Madagascar & 48 \\
\hline 12 & Eritrea & 47 \\
\hline 13 & India & 47 \\
\hline 14 & Somalia & 45 \\
\hline 15 & Sierra Leone & 44 \\
\hline 16 & Zambia & 42 \\
\hline 17 & Dominican Republic & 41 \\
\hline 18 & Ethiopia & 41 \\
\hline 19 & Nepal & 41 \\
\hline 20 & Nicaragua & 41 \\
\hline
\end{tabular}

* Source: UNICEF State of the World's Children, 2013 - data from UNICEF Multiple Indicator Cluster Surveys (MICS), Demographic and Health Surveys (DHS) and other national surveys, and refers to the most recent year available during the period 2002-2011. Source: United Nations

carry the scars of a difficult pregnancy and labour. Pregnant girls aged 15 to 19 are twice as likely to die in childbirth as women in their 20s, and girls under the age of 15 are five to seven times more likely to die during childbirth $^{6}$. These are due to physical immaturity where the pelvis and birth canal are not fully developed. Due to prolonged/obstructed labour many girls become victims of morbidities like obstetric Fistula ${ }^{7}$. Girls who give birth before the age of 15 have an $88 \%$ risk of developing fistula. Fistula patients are usually young girls who come from a socially disadvantaged group with little access to Emergency Obstetric Care. They suffer from incontinence orfaecaldischarge emitting foul odour making the girls social outcasts.

CHALLENGE TO THE ETHICAL RIGHTS OF GIRLS:"Child marriage is a huge problem in poor communities," says Nyaradzayi Gumbonzvanda, General Secretary of the World YWCA. "Early marriage and child marriage robs their future. Girls lose the opportunity for education. They lose the opportunity to choose their partner and must live with that pain for the rest of their lives" 8 .

Michelle Bachelet, Executive Director of UN Women ${ }^{3}$ states "No girl should be robbed of her childhood, her education and health, and her aspirations. Yet today millions of girls are denied their rights each year when they are married as child brides" 3 .

Once a girl is married at an early age she is deprived of her education and the opportunity to equip herself with life skills. She becomes a child mother before her body and mind are ready for this experience. The ill effects child marriage is reflected in the statements of Anthony Lake, Executive Director of UNICEF: "Child marriage is not only wrong, it is dangerous. It exposes a young girl to profound health risks from early pregnancy and difficult childbirth and it exposes her baby to complications of premature birth"3.

UNDERLYING CAUSES:Child marriage has existed for centuries, mainly because of tradition but also due to poverty. In early days parents used to arrange the betrothal of their infant children as a means of uniting two families. In present days the practice of early marriage is common in rural areas or where prospects for girls are few. The would -be brides have no say in the matter as guardians or other family members agree on the marriages and girls have no decision making options. 
Often girls are married early to provide protection, security and the support of a male guardian. The question of 'honour' is considered by parents and relatives, who may want to make certain the girls are married early to grooms approved by the families. According to a report by Girls Not Brides, "poverty is one of the most powerful drivers of the harmful practice in the country. Girls are thought of as an economic burden by parents who believe they will be more financially secure once their daughters are married off and out of their responsibility. Poor families want to reduce the number of children to feed, clothe and educate"9. Families may agree to child marriage because of community pressures and norms. Sometimes children who refuse to marry or choose a marriage partner against the wishes of their family may be punished or even killed ${ }^{10,11}$.

In recognition of the dreadful consequences of child marriage, many organizations are taking up global and country level programmes ${ }^{12}$. Some of these organizations are:

1. The Elders: The Elders are a group of independent global leaders launched by Nelson Mandela in Johannesburg in July 2007. The group offer their collective influence and experience to support peace building, help address major causes of human suffering and promote the shared interests of humanity. The principle is based on traditional village practices where communities take guidance ondifferent issues from elders. Similarly if the earth is thought of as a 'global village' then a group of experienced and dedicated elders could use their valuable experience and influence to focus on serious problems facing the world today. The Elders brought together local, national and international organisations in a global partnership to end the harmful practice of child marriage. This alliance is called Girls Not Brides: The Global Partnership to End Child Marriage.

2. Girls not Brides:As mentioned in the earlier paragraph, Girls Not Brides is an alliance of more than 500 civil society organisations from over 70 countries. These organizations have the aim to end child marriage to help girls to fulfil their potential.

Member organizations are from Africa, Asia, the Middle East, Europe and the Americas. The common vision is that every girl has the right to lead her life according to her choice. If the girl is not married early she can lead a safer, healthier life leading to a more prosperous future for herself, her family and her community. Girls Not Brides members bring child marriage to the forefront and advocate for the laws, policies and programmes that will make a difference in the life of millions of girls.

3. Plan International: Plan works with children in communities in 51 developing countries to advance the achievement of gender equality and girls' rights.

Through the 'Because I am a Girl 'campaign, Plan's projects address the barriers to girls completing a quality education of at least 9 years, as well as equip them with the assets they need to safe guard their future, promote gender equality and improve their lives.

4. CARE - Global: CARE is an international humanitarian organisation, which focuses on working for impoverished women. Their mandate includes directly addressing child marriage through targeting education for girls. CARE works with families, communities and local organisations to reduce the prevalence and mitigate the harmful impacts of child marriage through educational and behavioural- change programmes.

5. Girls UP - USA: Girls UP has dedicated advocacy and organisational efforts to ensure child marriage legislation is a priority in the US Foreign Policy Engagements. In March of 2013, their efforts were rewarded as the US House of Representatives passed the child marriage legislation as part of a broader Violence Against Women Act.

6. ICRW - USA: International Center for Research on Women (ICRW) is advocating for the United States to become more involved in curbing child marriage. ICRW works with the United States Congress and the administration to bring more national and international support to end this harmful practice.

7. Save the Children - Global: Save the Children works around the world to develop programmes to protect children and prevent child marriage along with other forms of child abuse, trafficking, and exploitation.

8. World Vision - Marriage Later/Studies First Programme - Bangladesh: World Vision works towards the provision of global education for children who are at risk for exploitation, early marriage, and lower incomeearning potential. In Bangladesh, they address barriers to education and work with communities and local governments to improve the quality of education children receive. The marriage later/studies first programme works with families to educate them on the impact of child marriage. 
9. The United Nations: The UN Resolution on Child, Early and Forced Marriage, was supported by 116 Member States at the 69th session of the General Assembly ${ }^{13}$.Every year, an estimated 15 million girls aged under 18 are married worldwide. In the developing world, one in nine girls is married before her 15th birthday .These children are robbed of their childhood, denied their rights to health education and security. The resolution calls on states, with the participation of relevant stakeholders, to develop and implement holistic, comprehensive and coordinated responses and strategies to eliminate child, early and forced marriage and to support already married girls, adolescents, and women through strengthening of child protection systems, protection mechanisms such as safe shelters, access to justice and the sharing of best practices across borders.

Child marriage is a global problem, but it is particularly widespread in African and Indo-Pacific countries. In Bangladesh, the percentage of women married before they turn 18 is $65 \%$, followed by $47 \%$ in India and $40 \%$ in Pakistan and Afghanistan.

UNFPA is committed to ending child marriage and reducing adolescent pregnancy by promoting legislation and programmes designed to end child marriage. UNFPA also supports investments that empower girls with the information, skills and services they need to be healthy, educated and safe. UNFPA also works to support the needs of married girls particularly in family planning and maternal health ${ }^{14}$.

UNICEF is working with partners in joint efforts to end child marriage. Together with governments, civil society and other agencies UNICEF is working to end child marriage globally. In 2011, 34 country offices addressed child marriage through social and economic change efforts and legal reform.

In India UNICEF supported the passage of the Child Marriage Prohibition Act of 2006, and the development and implementation of a national strategy on child marriage. UNICEF participated in the development of state action plans and supported work with the community on ending child marriage so girls will develop in a safe and productive environment.UNICEF estimates globally, almost 400 million women aged 20-49, (more than 40 per cent), were married in their childhood.

Child marriage puts girls at risk of early and unwanted pregnancies. Maternal deaths related to pregnancy and childbirth for girls aged 15-19 worldwide, account for some 50,000 deaths each year. Girls between 10 and 14 years of age are five times more likely than women aged 20 to 24 die in pregnancy and childbirth ${ }^{15}$.

POLICIES AND PROGRAMMES: Though many countries have legislation on age at marriage yet implementation becomes difficult. In Bangladesh, the Child Marriage Restraint Act of $1929^{16}$ passed during British rule is still applicable in Bangladesh, where the legal age for a girl to marry is 18.Unfortunately, enforcement efforts are weak, as is indicated by the high rates of child marriage in the country. A national law passed in 2004 requires that all births are registered, which would help determine a girl's age when she marries $^{17}$.

According to UNFPA,"In 2010, 158 countries reported that 18 years was the minimum legal age for marriage for women without parental consent or approval by a pertinent authority. However, in 146 countries, state or customary law allows girls younger than 18 to marry with the consent of parents or other authorities; in 52 countries, girls under age 15 can marry with parental consent. In contrast, 18 is the legal age for marriage without consent among males in 180 countries. Additionally, in 105 countries, boys can marry with the consent of a parent or a pertinent authority, and in 23 countries, boys under age 15 can marry with parental consent" ${ }^{14}$.Some countries position has been shown in Table 2.

WAY FORWARD: A policy brief by ICRW highlights five evidence-based strategies identified to delay or prevent child marriage ${ }^{18}$.

1. Empower girls with information, skills and support networks: If young girls know better their options this will strengthen them to act and advocate for themselves. These girls will gain the confidence to look for jobs and alternatives to marriage and guardians will re-consider marrying them off early, which will ultimately impact on changing of traditions and values on child marriage.

Essential training on Life skills, Vocational and livelihoods skills as well as Reproductive Health information will help to teach girls about health, nutrition, money, finance, legal awareness, communication, negotiation, decisionmaking and other relevant topics 
2. Educate and rally parents and community members: With parental and community support and involvement a more enabling environment will be created. As it is the parents and guardians who take the decision regarding when or whom the girls will marry, with parental education and community mobilization a more supportive environment for girls can be attained. This will lead to families willing to change the custom of early marriage.

3. Economic support and incentives to girls and their families: Poverty is a strong reason for early marriage. The value and contribution of the daughter would increase if the families would perceive her accessibility to

Table 2 shows the Wikipedia on Marriageable Age which providesthe following information ${ }^{19}$.

\begin{tabular}{|c|c|c|c|}
\hline Country & $\begin{array}{c}\text { Male } \\
\text { Consent } \\
\end{array}$ & $\begin{array}{l}\text { Female } \\
\text { Consent }\end{array}$ & Notes \\
\hline Bangladesh & 21 & 18 & $\begin{array}{l}\text { Bangladeshi law provides penal sanctions for the contraction of } \\
\text { under-age marriages, although such unions are not considered } \\
\text { invalid Despite the law, child marriage rates in Bangladesh are } \\
\text { among the highest in the world. Every } 2 \text { out of } 3 \text { marriages } \\
\text { involve child marriages. }\end{array}$ \\
\hline India & 21 & 18 & $\begin{array}{l}\text { If any partner(s) engages in marriage at a younger age, (s)he } \\
\text { can ask for the marriage to be declared void. A recent } \\
\text { recommendation by the Law Commission aims to equalize the } \\
\text { marriage age for males and females to } 18 . \text { Official policy } \\
\text { automatically declares marriages under } 16 \text { as "null and void", } \\
\text { while marriages at the age of } 16 \text { or } 17 \text { are "voidable". In } 2012 \text {, } \\
\text { the high court declared that Muslim women can marry at } \\
\text { 15. Additionally, the report declares that "In spite of these legal } \\
\text { provisions, child marriage is still widely practiced and a marriage } \\
\text { solemnized in contravention of these provisions is not void even } \\
\text { under the new PCMA, 1929, the Hindu Marriage Act, } 1955 \text { and } \\
\text { also under the Muslim Law. }\end{array}$ \\
\hline Afghanistan & 18 & 16 & $\begin{array}{l}\text { In some cases, even younger girls are forced to marry at the age } \\
\text { of } 8 \text {. }\end{array}$ \\
\hline Pakistan & 18 & $\begin{array}{l}16 \\
(18 \text { in } \\
\text { Sindh })\end{array}$ & $\begin{array}{l}\text { Despite the law against child marriage, the practice is } \\
\text { widespread. According to two } 2013 \text { reports, over } 50 \% \text { of all } \\
\text { marriages in Pakistan involve girls less than } 18 \text { years } \\
\text { old.Another UNICEF report claims } 70 \text { per cent of girls in } \\
\text { Pakistan are married before the age of } 16 \text {. Another custom in } \\
\text { Pakistan, called swara or vani, involves village elders solving } \\
\text { family disputes or settling unpaid debts by marrying off girls. The } \\
\text { average marriage age of swara girls is between } 5 \text { and } 9 \text {. }\end{array}$ \\
\hline Zimbabwe & 18 & 16 & With parental consent. \\
\hline Niger & 18 & 15 & Under with parental consent. \\
\hline Tanzania & 18 & 14 & With parental consent \\
\hline Bhutan & 18 & - & \\
\hline Kenya & 18 & - & 16 with parental consent males. \\
\hline Maldives & 18 & - & $\begin{array}{l}\text { According to custom, the minimum age for marriage is } 15 \text {. The } \\
\text { Law on the Protection of the Rights of the Child discourages } \\
\text { marriage before the age of } 16 \text {. }\end{array}$ \\
\hline Nepal & 20 & - & 18 with parental consent. \\
\hline Sri Lanka & 18 & - & $\begin{array}{l}\text { However, the parties must have a Quazi's permission to marry } \\
\text { before contracting into marriage if they are Muslims. }\end{array}$ \\
\hline
\end{tabular}

other economic opportunities as an alternative to marriage. Thus if scholarships and stipends are tied to the condition that girls cannot marry until 18, parents will try to keep their daughters in school.

4. Enhance girls' access to a quality education: When girls are in a formal school they are usually looked upon as a child. Again the school provides a safe haven for the girls and it also improves their quality of life. If this is tied with stipend then parents will try to keep their daughter in school. 
5. Encourage supportive laws and policies: Though many countries have laws and policies prohibiting child marriage yet enforcement has been difficult. In order to bring about acceptance and implementation of these laws ICRW suggests a multi-strategy approach, combining legal advocacy with other community or girl-focused approaches. Raising awareness among the community on the consequences of child marriage together with information on the existence of the law would help in bringing about a reduction in child marriage. The ICRW researchers recommend that "In order for the next generation of development programs to make ending child marriage a priority, policymakers must pay attention to these strategies while continuing to test innovative approaches and evaluation techniques."

CONCLUSION:Though there is substantive work initiated to reduce the incidence of child marriages, yet a lot remains to be done to attain Zero Child Marriage. Each country has to set up its own mid-term and long term goals to bring about significant reduction in child marriages. The issue is not an isolated one rather it is intertwined with social norms, cultural taboos and traditions and economic conditionsof the families. Partnerships with related Government agencies, NGOs, Media, Women's groups and the private sector will lead to a faster attainment of goals. The problem when addressed through a holistic approach with clearly defined indicators, milestones and responsibilities will help families, communities, nations and regions achieve Zero Child Marriages in a defined time period.

CONFLICT OF INTEREST: None to declare.

\section{REFERENCES:}

1 UNICEF. Child protection from violence, exploitation and abuse. Updated: 2014 October 22

2 United Nations Treaty Collection. Convention on the Rights of the Child. Retrieved 2015 October 2

3 UNFPA, UNICEF, WHO, UN Women, the United Nations Foundation, World Vision, Girls Not Brides, Every Woman Every Child, World YWCA and The Partnership for Maternal, New born and Child Health. Joint press release [Internet]. 2013 March 7 [cited 2015 July 10]. Available from: http://www.unwomen.org/en/news/stories/2013/3/child-marriages

$4 \quad$ PMNCH Knowledge Summary \#22 Reaching Child Brides. The Partnership for Maternal, New born and Child Health. 2012

5 Child Marriage and Domestic Violence. International Center for Research on Women ICRW. 2006

$6 \quad$ Nour Nawal M. Health Consequences of Child Marriage in Africa. Emerging Infectious Diseases. 2006; 12(11): 1644-1649

7 Cook, Rebecca J., Bernard M. Dickens, and S. Syed. Obstetric Fistula: The Challenge to Human Rights. International Journal of Gynecology and Obstetrics. 2004; 87:72-77

8 Gumbonzvanda N. Ending Child, Early and Forced Marriage. Presentation in UN Panel Discussion Campaign to End Child Marriage. 2015

9 Girls Not Brides. News on Impact of Child marriage [Internet].2015. [Cited 2015 August]. Available from http://www.girlsnotbrides.org/what-is-the-impact/

10 BBC. Ethics Guide, Honor Crimes [Internet]. 2012 [cited 2015 July 10]. Available from: http://www.honordiaries.com/wp-content/uploads/2013/06/HD-FactSheet-HonorViolenceEast.pdf

11 BBC. Ethics - Honour Crimes [Internet]. bbc.co.uk

12 Olson C. The Pixel Project's "16 For 16" Campaign.16 Organizations Working to Stop Child Marriage. 2013 December 6

13 United Nations General Assembly. Child, Early and Forced Marriage. Sixty-ninth session Agenda item 65(a) Resolution Adopted by the General Assembly 69/XX

14 UNFPA. News on Child marriage [Internet]. 2015[Cited 2015 July 10]. Available from: http://www.unfpa.org/child-marriage

15 UNICEF. Child Protection from Violence, Exploitation and Abuse. 2011 
16 Ministry of Law, Justice and Parliamentary Affairs, Bangladesh .The Child Marriage Restraint Act, 1929. (Act No. XIX of 1929)

17 Bangladesh Gazette Additional Publication. The Births and Deaths Registration Act, 2004. 2004 December 7

18 Malhotra A. Solutions to End Child Marriage: What the Evidence Shows. ICRW Publication. 2011

19 Wikipedia [Internet]. [Cited 2015 July 10]. Available from https://en.wikipedia.org/wiki/Marriageable_age 